\title{
My journey from Japan to becoming a physician-scientist in the United States
}

\author{
Yumi Imai ${ }^{1,2}$ \\ 'Department of Internal Medicine, Carver College of Medicine, Fraternal Order of Eagles Diabetes Research Center, University of lowa, lowa City, lowa, USA. ${ }^{2}$ lowa City Veterans Affairs Medical Center, \\ lowa City, lowa, USA.
}

"W elcome, Yumi. Please call me Marian, not Dr. Young. We use first names here." Thus my first day in the US as a research fellow at the National Institutes of Health (NIH) started with a greeting remarkably different from what I was used to in the highly hierarchical society of Japan. In a time when one in five researchers in biomedical sciences in the US is an immigrant (1), I hope that sharing my experience of becoming a physician-scientist will highlight the strengths of the US biomedical research community in nurturing scientists from various backgrounds and creating diversity and dynamism in the field.

\section{Coming to the US}

After graduating from the Tohoku University School of Medicine in Sendai, Japan, I completed five years of clinical training in internal medicine and endocrinology at Toranomon Hospital in Tokyo, Japan, before coming to the US with little research experience. I received my first full-time training as a research fellow at the NIH for five years and then completed a three-year postdoctoral fellowship at the University of North Carolina at Chapel Hill. Then, I went back to clinical training and completed an internship and residency in internal medicine at the Interfaith Medical Center in Brooklyn, New York, followed by a fellowship in endocrinology, diabetes, and metabolism at the University of Pennsylvania, where I started my path as a physician-scientist and developed my research interest in $\beta$ cell dysfunction. I obtained my first faculty position at Eastern Virginia Medical School and rose to the rank of Associate Professor and Division Director. I am now at the University of Iowa's Carver College of Medicine, where I have an endowed professorship in diabetes research. In short, I spent 18 years in training, twice as long as the average time to fully train to be a physician-scientist in the US. This occurred largely because of differences between the education systems in Japan and the US and restrictions imposed by immigration and regulatory agencies.

\section{What is a physician-scientist?}

This is not a philosophical question. This was indeed a very simple question that I asked myself during my early days in the US. This career path was unknown to me until I had the opportunity to observe and interact with physician-scientists at the NIH. In Japan, the percentage of physicians holding a $\mathrm{PhD}$ degree is high and is over $60 \%$ in my generation. Japanese MDs pursue a $\mathrm{PhD}$ after completing residency training and before moving on to clinical practice for the rest of their career. In Japan, most individuals with MD and $\mathrm{PhD}$ degrees in my generation received $\mathrm{PhD}$ training without much opportunity to continue research, with the exception of a few who were chosen by their professors to remain in academia. This system is very different from that in the US, where students have the option to enroll in combined $\mathrm{MD} / \mathrm{PhD}$ programs that foster opportunities for physicians to pursue a research career at a very early stage. The US system also supports the continued development of physician-scientists into independent researchers through postgraduate training for individuals with $\mathrm{DO}$, $\mathrm{MD}$, and $\mathrm{MD} / \mathrm{PhD}$ degrees.

Following a typical career path of a Japanese MD, I came to the NIH after completing clinical training, hoping to complete research that would allow me to defend a PhD thesis in Japan. When I arrived in the US, my plan was to work on research toward my $\mathrm{PhD}$, experience life in America, and then return to Japan to practice as an endocrinologist until retirement. In a sense, I had a very carefree situation, because I was under little pressure to find my niche in research or establish a career in the US. This was a precious period when my love for research deepened purely by being involved in it. As I became more captivated by the quest to find answers to unsolved questions, the prospect of life back in Japan as a clinician began to look uninteresting and dull. However, it could have ended with me just admiring with a little envy the life of a physician-scientist in the US as I packed to return to Japan. Then, a twist of fate made me change plans: I married a Polish postdoc who also worked at the NIH.

\section{Becoming a physician-scientist in the US}

For a Japanese and a Polish postdoc to find common ground professionally, staying in the US was the ideal solution. However, this decision was challenging, because both of us held J1 visas that were about to expire during a government hiring freeze. Immigration status dominated our careers for the next several years until we became permanent residents. I was extremely fortunate to have two key mentors who guided my career decisions through this uneasy period. Dr. Simeon Taylor, a physician-scientist, was my research mentor at the Diabetes Research Branch of the National Institute of Diabetes and Digestive and Kidney Diseases (NIDDK) and always gave the wisest advice to his trainees. He advised me that it would be best for my career to obtain clinical credentials and work toward becoming a physicianscientist in the US. He introduced me to Dr. David Clemons, who was chief of the 
Division of Endocrinology at the University of North Carolina at Chapel Hill, and I could continue training as a research fellow while we made progress with our immigration status. In addition to obtaining valuable research experience, I saw in Dr. Clemons a great physician-scientist role model. He was in his office next to the laboratory from Monday to Thursday, had his endocrine clinic on Friday, and wrote or read in his office on Saturdays. While being a devoted scientist, he was a very relaxed and warm physician when I shadowed him in the clinic. Dr. Clemmons was seamlessly combining his two main professional roles, which further motivated me to become a physician-scientist. However, I encountered my biggest obstacle when I applied for residency in the US, because it had been more than 10 years since I graduated from medical school. In addition, I was not aware that I was competing against 10,000 international medical graduates (IMGs) applying for residency each year in the US, most of whom had been preparing for the US residency exam requirements since medical school. When it became clear that my chances of being selected for an academic-affiliated residency program were slim, I approached Dr. Clemmons with one question: Does residency at a community hospital end my quest to become a physician-scientist? To my relief, his answer was no. I would be judged for both my research and clinical training when applying for a fellowship in endocrinology. Keeping his words in my heart, I started my training in internal medicine in an underserved area of Brooklyn, New York, while my family, which now included a two-year old son, remained in North Carolina. While I greatly benefited from three years of solid clinical training overseen by the Accreditation Council for Graduate Medical Education (ACGME), there was an undeniable lack of exposure to basic research and an interruption in my research career during my residency.

\section{At last a physician-scientist in the US}

After my internal medicine residency and board certification, I became an endo- crinology fellow, hoping to finally combine my interests in clinical medicine and basic research. Despite my atypical path, I was given the opportunity to join the Division of Endocrinology at the University of Pennsylvania, led by Dr. Mitchell Lazar. This was the perfect environment for me to engage in diabetes and obesity research. After completing my clinical fellowship, I resumed basic research under the guidance of Dr. Rexford Ahima. He laid out a clear goal for me to develop an independent project and provided tremendous support for me to carry it out. With my "green card" (permanent US resident status), I was eligible for T32 grant support for two years of a research fellowship. I was subsequently awarded an NIH KO8 grant to study $\beta$ cell dysfunction in obesity. Looking back, my scientific readiness and eligibility to compete for a career development award were pivotal in my work toward becoming a physicianscientist in the US. Since then, I have kept a foothold in academia that allows me to split my time between basic research and patient care. As a physician-scientist, it is always challenging to maintain a balance between research and clinical work, as this entails earning protected time through grants and institutional support so that my research progresses and remains productive. However, this is not unique to an immigrant scientist, but universal for all physician-scientists pursuing a successful career in the US.

\section{Personal reflections}

My journey in the US has been shaped by successive mentor-mentee relationships starting from my time at the NIH. It continues even to the present day in my career progression as a faculty member at the University of Iowa. I believe that strong mentor-mentee relationships are critical, in that they cultivate the knowledge and growth of the next generation of scientists. A mentor's openness to welcome and guide a mentee following an atypical path is part of a culture that incorporates researchers with diverse backgrounds, which in turn has sustained an unparalleled dynamism in US biomedical research. Now I hope to hand my experience down to the next generation of scientists and physicians.

I am extremely grateful for the career I have in the US and for all of my research experiences. If I had returned to Japan, my research career would likely have ended after five years at the NIH. At the same time, I have an ambivalent feeling about the prolonged training I endured. To be constructive, I try to use my first-hand experience in broad areas of research and my in-depth clinical experience to provide a unique perspective to the field as a physician-scientist. However, from time to time, I ask myself whether I could have been more productive if I had decided to be an independent researcher earlier in my career. As I increasingly play the role of mentor, it is my hope that I can strongly support the development of my mentees and maximize the potential of each one through productive research and individualized guidance, irrespective of immigration status or background.

\section{Acknowledgments}

I wish to express my gratitude to all the mentors I have had throughout my career in the US (Drs. Vincent Hascall, Masaki Yanagishita, Simeon Taylor, Domenico Accili, David Clemmons, Mitchell Lazar, Rexford Ahima, Franz Matschinsky, Jerry Nadler, Romesh Khardori, and Dale Abel) and dedicate this to Dr. Yoshimasa Shishiba, who was the chief of Endocrine Section at Toranomon Hospital, Tokyo, Japan, for planting in me a passion for endocrinology and research. I thank Dr. Marcelo Correia for critical reading of this manuscript. YI is supported by grants from the NIH (R01DK090490), the Department of Veterans Affairs (I01 BX005107), and the Fraternal Order of Eagles Diabetes Research Center at the University of Iowa.

Address correspondence to: Yumi Imai, 200 Hawkins Drive, PBDB Rm 3318, Iowa City, Iowa 52242, USA. Phone: 319.335.4844; Email:yumi-imai@uiowa.edu.

1. Khullar D, et al. US immigration policy and American medical research: the scientific contributions of foreign medical graduates. Ann Intern Med. 2017;167(8):584-586. 